\title{
GM corn poses little threat to monarch
}

Despite some uncertainties, the monarch butterfly faces little threat from genetically modified (GM) strains of corn, according to new research presented at a symposium sponsored by the biotechnology industry. Although agricultural scientists admit that more research into the butterfly's real-life interaction with corn needs to be done, they agree that earlier characterizations of peril to the butterfly were likely overstated.

The findings were presented by the Agricultural Biotechnology Stewardship Working Group-a consortium of agribusiness firms-at a one-day symposium and press conference held near Chicago on November 2. The symposium and studies were organized in response to a report last May by Cornell University researchers who found that high proportions of monarch larvae died after being force-fed milkweed plants that were covered by pollen from GM corn (Nature, 399, 214, 1999). Plant scientists and representatives of life science companies criticized the work as premature and incomplete (Nat. Biotechnol. 17, 627, 1999).

"The worst-case image of this toxic cloud of pollen saturating the Corn Belt and wiping out the Lepidoptera species including monarchs is clearly not the case," says Stuart Weiss, a Stanford University researcher. "The pollen has a limited shadow (distribution) and the toxicity of the pollen is not as toxic as thought."

The GM corn contains genes for a protein from a common soil bacterium, Bacillus thuringiensis $(B t)$, and is prevalent in more than $30 \%$ of the corn grown in the United States. Milkweed plants, a favorite food of butterfly larvae, grow within and around the edges of cornfields.

Several lines of evidence presented at the conference suggest GM corn presents little threat to monarch larvae. Galen Dively of the University of Maryland noted that pollen concentrations drop off rapidly several meters from the cornfield, suggesting that milkweed farther away will be relatively pollen free. Other data presented showed that various strains of $B t$ corn had differing rates of toxicity to monarchs, that harmful pollen is often washed off or blown off milkweed leaves, and that $95 \%$ of corn pollination in Nebraska was complete before the first monarch eggs hatched. (Adult butterflies feed on plant nectar and are not affected by toxin-containing pollen.)

In the earlier Nature paper, Cornell entomologist John Losey used a low toxic strain of pollen. He presented new research in Chicago showing that adult monarchs avoided laying eggs on milkweed leaves near corn plants and those covered with pollen.

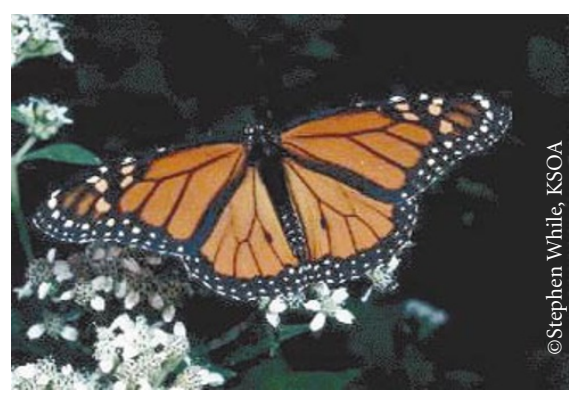

However, Chip Taylor, an ecologist at the University of Kansas, says scientists still don't know the real-world interaction between butterfly larvae, milkweed, and corn pollen. "What we need to know is how much monarchs are using milkweed at the edge of corn plants and their rates of morbidity and mortality," he says. "We still don't have that."
Of the 20 studies presented at the conference, $60 \%$ were funded by the industry group, which included Monsanto (St Louis, MO), Novartis AG (Basel, Switzerland), and Pioneer Hi-Bred (Des Moines, IA), which is owned by DuPont. The remainder were funded by individual institutions or the US Department of Agriculture (Washington, DC).

"We all agree that we have some of the data we need," says Losey, "But the question of risk assessment still hasn't been answered."

Some critics argue that the studies reported at the meeting were too short and were not put through the peer-review process before being presented to the public. "There are a lot of conclusions being made on very preliminary data," says Rebecca Goldburg, a senior scientist at the US Environmental Defense Fund, "It seems a little premature."

Eric Niiler

\section{Patent case unblocks antibody businesses}

When two companies are involved in a patent dispute, there can only be one winnerexcept, it seems, when methods for developing improved antibodies are concerned. When the European Patent Office's (EPO; Munich, Germany) opposition division upheld Cambridge Antibody Technology's (CAT; Melbourne, UK) key "Winter II" patent at the end of October, both CAT and MorphoSys (Munich, Germany), which had opposed the patent, claimed victory. "Favorable Decision in EPO Opposition Proceedings," read the CAT release; "MorphoSys Prevails in CAT Patent Dispute" was how the MorphoSys spin machine saw it. However, even though other intellectual property (IP) disputes between the two parties are still outstanding, the recent decision may indeed benefit both, simply because it unplugs the sclerosis of indecision that had stifled the businesses of both concerns.

The patent was granted originally by the EPO in 1994 and was opposed by MorphoSys soon afterward. "Although we opposed the patent in its entirety," says Simon Moroney, MorphoSys' CEO, "we were only really concerned about claim 32 .” While the other claims are to technical details of CAT's PCR-based approach to phage display techniques for antibody development, claim 32 originally sought more general protection and appeared to cover virtually all methods of producing libraries of antibody genes. MorphoSys was con- cerned that the claim encompassed its own $\mathrm{HuCAL}$ (human combinatorial antibody library) method. MorphoSys thus endeavored to get the EPO to restrict claim 32 to what CAT has actually demonstrated in its patent application.

\section{The decision may benefit both companies simply because it unplugs the sclerosis of indecision that had stifled the businesses of both concerns.}

Moroney suggests that the October decision of the EPO "was in line with narrowing the claim". What CAT has actually shown, says Moroney, was that the method works with one particular gene and one particular CDR (complementarity-determining region). The claim now reads, "an expression library comprising a repertoire of third CDR sequences, said sequences being located in an otherwise invariant VH gene.” This means, says Moroney, that the Winter II patent now means that CAT has IP rights on techniques that allow the development of antibodies by "plugging in a bunch of VH3 variants."

Despite the protestations from MorphoSys that the application no longer encompasses its HuCAL Library, 